\title{
Central Banks
}

\author{
Jens van 't Klooster
}

To appear in: The Cambridge Handbook of Constitutional Theory, edited by

\section{Richard Bellamy and Jeff King}

Although their constitutional independence has varied historically, today most central banks are placed at arm's length from elected government. Their independence, moreover, is often part of the written constitution, with at least 78 national constitutions referencing the status of their central bank (Constitute Project, 2020). Under central bank independence, the power to issue public money is delegated to a committee of unelected officials within the central bank, often appointed on recommendation of the central bank. Positions come with long, fixed terms. Once appointed, only serious acts of misconduct can be cause for dismissal. Central banks make their decisions in isolation from politicians. Their mandates, however, tend to provide central bankers with only the most generic guidance on what to do. What should legal and political theorists make of the institutional structures of central bank independence?

The most widely used democratic argument to justify central bank independence treats it as a case of bureaucratic delegation like any other. A prominent recent exponent of this view is former central banker Paul Tucker in his recent Unelected Power (2018). Bureaucratic delegation involves assigning to unelected officials a set of clearly defined instruments, which they are meant to use in pursuing clearly defined goals. Although accounts that treat central bank independence as a case of bureaucratic delegation usually do not deny that central bankers make some choices, major distributional choices are meant to be made in the act of delegation, rather than by the central bank itself. Setting monetary policy is treated as a technical issue, which concerns how to achieve goals in the most efficient way, rather than setting those goals itself. This approach thereby sidesteps the many interesting questions that emerge once we acknowledge that central bankers do make important political choices.

This chapter provides an overview of the state of the art in constitutional theory with regard to the topic of central banks. It challenges accounts of central banking as involving limited discretion and distributional choices, as well as the narrow range of normative questions that such accounts raise. The chapter also provides a roadmap for a vast range of procedural and substantive issues raised by independent central banks, thereby highlighting just how much of the terrain remains underexplored.

The first part of the chapter studies the unique role of central banks within the broader 'monetary constitution'. Existing monetary constitutions involve both public and private money creation. Central banks do not usually provide credit to the real economy directly, which is a prerogative of private financial institutions. Central banks' most important roles concern the management and regulation of private money. The structure of this monetary constitution is usually not written down in written constitutions narrowly understood. Rather, it receives effect from a range of legal texts, which include legislative instruments concerning banking, sovereign debt and the central bank mandate. 
The second part of the chapter turns to the politics of monetary policy and the way in which central bankers interpret their mandates. It is in this context that central bankers themselves routinely present their activities as an instance of bureaucratic delegation. For one, central bankers justify choices they make by suggesting that they are decided by their legal mandate. Central bankers also play down the far-reaching consequences of their choices. Although they on occasion admit that monetary policy has pervasive short-term effects, the choices that central bankers make are not meant to involve distributional choices. Where monetary policy impacts the economy, it is thought to be neutral in various senses of the term. I discuss these wide-spread ideas to show that central bankers make choices and that monetary policy has a material impact on society that is anything but neutral.

The final part of the chapter turns to the question of what to make of central bank independence from a normative perspective. As I argue, some delegation of important decisions to unelected officials is almost unavoidable, often desirable and by itself not undemocratic. I then explain why we should nonetheless be reluctant to allow for extensive central bank discretion by highlighting six crucial issues that are currently not sufficiently understood: Their actual level of autonomy from governments, the effectiveness of accountability mechanisms, the effects of depoliticizing money on the broader political system, the effects of democratic insulation on the effectiveness of central banks, the specific practices of deliberation within central banks and the scope for coordination with elected government.

\section{The central bank and the monetary constitution}

The way in which the private and the public are interrelated in different historical capitalist societies has some strikingly invariant features (Braudel, 1982; Ingham, 2004; Arnon, 2010; Desan, 2014). Recently, this structure has been characterized as a hybrid public-private franchise system (Hockett \& Omarova, 2017) and as a money-credit constitution (Tucker, 2018). I describe it as a monetary constitution, which is a hybrid of both public and private authority over money. I identify three key normative principles that characterize today's hybrid constitutions.

\section{The monetary constitution}

A helpful way of expressing the idea of a monetary constitution, is as the total laws and constitutional conventions that govern (i) how authority over the provision of money is distributed; (ii) which actions are permissible and which are compulsory for those who hold monetary authority; and (iii) how different actors are to exercise their authority (van 't Klooster, 2018). This conception of the monetary constitution is wider than currently common uses of the term, where it refers to the central bank's mandate (Yeager, 1962; Brennan \& Buchanan, 1980) or simply the conditions under which the central bank can issue public money. Milton Friedman, for example, talks of the need for "a monetary constitution, which takes the form of rules establishing and limiting the central bank as to the powers that it is given, its reserve requirements, and so on" (Friedman, 1962, p. 255). This narrow conception ignores how a monetary constitution can also create a private sphere in which the state does not interfere with the issuance of money. Not all conceivable monetary constitutions involve both forms of authority. The authority over money could be entirely under public control. Socialist economies are examples but there are also proposals to prohibit private money creation within a broadly market-based 
economy (Jackson \& Dyson, 2012; Kumhof \& Benes, 2012; Weber, 2018). Alternatively, as proposed by libertarian free bankers and some recent proponents of cryptocurrencies, the authority over money could be left entirely in private hands (Selgin, 1988; Nakamoto, 2008).

Existing monetary constitutions give effect to a hybrid system, which involves both public and private money creation (Moore, 1988; Graziani, 2003). Central banks issue cash and central bank deposits. A central bank deposit (also called reserve) is a balance on a central bank account, which is typically owned by a financial institution to settle large volume payments. Central banks issue money by either lending to commercial banks or by buying high-quality financial assets. These transactions, however, take place within financial markets far removed from most citizens. The central bank does not, save in exceptional circumstances, provide credit to the real economy. Citizens and nonfinancial firms currently do not receive cash directly from the central bank nor do they have central bank accounts (Barontini \& Holden, 2019). Instead, the volume of money circulating in the real economy is largely determined by banks, which issue new deposits through the act of granting loans to citizens and non-financial firms. Non-bank financial institutions (including hedge funds, insurance companies and pension funds), meanwhile, engage in so-called shadow banking, where they seek to issue financial instruments with money-like characteristics, while simultaneously avoiding the strict regulatory framework applied to banks (Mehrling, 2010; Gabor \& Vestergaard, 2016; Murau, 2017).

\section{The central bank}

Monetary constitutions are not written down in a document, nor are the key features of how authority over money is allocated part of written constitutions narrowly understood. The key legal features that characterize existing hybrid monetary constitutions can be summarized in terms of three normative principles.

The first principle is that public money is issued by a central bank rather than by the government. This serves to ensure that fiscal authorities do not pay for expenditures by issuing new money (Turner, 2015; Ryan-Collins, 2017) Instead, governments need to finance any expenditures in excess of tax revenues by issuing debt to the private sector, leaving the issuance of public money solely for the purposes of executing monetary policy decisions of the central bank. The creation of central banks is historically often motivated by the desire to place money creation at armlength from the Treasury. In some historical cases, such as the pre- $20^{\text {th }}$ century Bank of England, the issuer of public money is explicitly prohibited from lending to governments without parliamentary approval for each discreet line of credit (Bateman, 2020). Some central bank laws explicitly prohibit operations whereby the central bank issues money to enable an expansion of government expenditure (so-called monetary financing). Even in the absence of an explicit rule, however all hybrid monetary constitutions make a clear distinction between the monetary and the fiscal activities of the state.

Beyond being banned from paying for government expenditures, central banks are also expected to refrain from providing funds directly to individual citizens and nonfinancial firms. This is a second normative principle that informs the design of central bank mandates, which usually contain provisions that spell out eligible counterparties for central banks and the types of assets that they can trade in. Despite considerable historical variation (Braun \& Downey, 2020), central banks today tend to focus their activities on 
lending to banks and trading in government bonds, valuable metals, and other safe assets. Lending directly to citizens and firms, in contrast, is not usually an explicit part of the central bank toolbox. The past decade has made clear that existing central bank mandates provide legal options for central banks to influence the real economy, but central bankers remain very reluctant to do so (Johnson, Arel-Bundock, \& Portniaguine, 2019). By limiting central bank operation to the purchase of safe assets and lending to banks, the legislature codifies the hybridity of the monetary system. Where central banks are not actually constrained in their choice of instruments, the choice for a narrow toolbox can be understood as a constitutional convention. Lending to citizens and non-financial firms is not strictly prohibited, but it is frowned upon and subject to moral condemnation.

The third normative principle that underpins hybrid monetary constitutions is that private institutions are only allowed to issue money subject to a strict public regulatory framework (Admati \& Hellwig, 2014; Ricks, 2016). Banks, in virtue of their ability to create money through lending, tend to be amongst the most tightly regulated private firms. At the same time, however, allowing for competition between banks is meant to incentivize an efficient allocation of credit. Competition is to incentivize them to offer high quality, or at least similar quality, products. Competition is also meant to cause profit rates for banks to gravitate around the general rate of profit in the economy. If a product or sector is particularly profitable, new competitors are meant to move into the market. The regulatory framework seeks to ensure that the owners that stand to benefit from profits also face any losses that result from the operations of the bank. Again, this objective is not typically an article in the written constitution, but rather part of the broader normative ideas which guide legislatures, central banks and other public actors.

In giving effect to this third principle, central banks hold two key roles. First, many (but not all) central banks regulate and supervise financial institutions. The Financial Crisis of 2007 and 2008 has illustrated that financial institutions continually contest the actual legal and political constraints on private money creation (Pistor, 2013; Murau, 2017). Banks have an incentive to go to the limits of the regulatory framework, and sometimes beyond, which leads them to invent new financial products and other ways of skirting existing regulation. Central banks are often not only tasked with applying banking law but also devise the very regulatory standards that they apply. In the context of the Basel Committee for Banking Supervision central bankers set the main outlines of banking law (Brummer, 2015). The second role that central banks have in relation to the private segment of the monetary system is that of designing and implementing monetary policy. Through monetary policy central banks seek to steer how much money banks create, which allows them to indirectly influence price levels. Monetary policy operations also serve financial market objectives such as that of serving as the lender of last resort of the banking system. Lending to banks is an important part of day to day central bank operations, which acquires existential importance to banks when customers withdraw deposits and money market funding runs out (BIS, 2014). Today central bankers also hold various roles as market makers of last resort to stabilize asset prices and provide nonbank financial institutions with funding (Mehrling, 2010).

\section{The politics of monetary policy}

The most interesting constitutional questions concerning central banks arise from their large discretion in exercising political power. To study the nature of the discretion 
available to central banks, I now turn to monetary policy, which is at the core of democratic justifications of central bank independence. I show that even within the confines of the hybrid monetary constitution, central bankers have considerable discretion, which routinely confronts them with important distributional choices.

\begin{tabular}{|c|c|c|}
\hline & Content & Constitutional authority \\
\hline Mandate & $\begin{array}{c}\text { General provision on goals and } \\
\text { instrument }\end{array}$ & Legislature \\
\hline Objectives & $\begin{array}{l}\text { Empirical and quantitative } \\
\text { operationalization of objectives and } \\
\text { ordering their priority }\end{array}$ & $\begin{array}{l}\text { Central bank and sometimes modest } \\
\text { role for the executive }\end{array}$ \\
\hline $\begin{array}{l}\text { Monetary policy } \\
\text { strategy }\end{array}$ & Operational targets and instruments & $\begin{array}{l}\text { Multi-annual review within the central } \\
\text { bank }\end{array}$ \\
\hline $\begin{array}{l}\text { Monetary policy } \\
\text { setting }\end{array}$ & $\begin{array}{c}\text { Setting the target value of the operational } \\
\text { target }\end{array}$ & Central bank board or committee \\
\hline $\begin{array}{l}\text { Monetary policy } \\
\text { Implementation }\end{array}$ & $\begin{array}{l}\text { Trading to influence the operational } \\
\text { target }\end{array}$ & $\begin{array}{l}\text { Central bank board and market division } \\
\text { within the central bank }\end{array}$ \\
\hline
\end{tabular}

Figure 1 Four steps in the interpretation of a central bank mandate

\section{Choices}

To analyse the actual discretion available to independent central banks, I distinguish four interpretive steps that move from the central bank mandate to actual monetary policy operations (See Figure 1). In all four steps central bankers make important choices.

The first step in the interpretation of the mandate is to determine the objectives of monetary policy (Lastra, 2015; Dikau \& Volz, 2021). The decision on the objectives operationalizes the aims of the central bank so that they can be measured empirically and quantitatively. This may involve various aims such as one or more specific inflation metrics, a growth number, unemployment statistic and/or exchange rate. Where a central bank has multiple targets of equal weight, it needs to decide how to settle conflicts. The objectives tend to be only spelled out in the mandate in general terms. The most austere mandates simply state that the central banks should pursue price stability without further qualification. The Bank of Japan Act, for example, states that monetary policy should be "aimed at achieving price stability, thereby contributing to the sound development of the national economy.", with the qualification that "the basic stance of the government's economic policy shall be mutually compatible." (Bank of Japan Act of June 18, 1997, Article 2 and 5). Other central banks have an explicit mandate to support the economic policies of governments. Both the price stability objective and other objectives outlined in the mandate tend to be generic and only derive their meaning from interpretation. This vagueness is compounded when the mandate contains multiple aims. For example, the Federal Reserve is to "promote effectively the goals of maximum employment, stable prices, and moderate long-term interest rates" (US Federal Reserve Act, Section 2A), but the statute provides no guidance on how to deal with conflicts between these various objectives. The Federal Reserve has set its own target as that of "inflation at the rate of 2 
percent, as measured by the annual change in the price index for personal consumption expenditures", whereas maximum employment is understood as a long-term equilibrium that changes over time and is debated at individual meetings (FOMC, 2020). Although most central banks set their ultimate target themselves, some decide it together with the executive. The Reserve Bank of New Zealand makes this decision on the basis of a bilateral agreement with the government. Amongst the world's major central banks, the Bank of England alone receives an operationalization of its target from the Treasury.

The second step in the interpretation of the mandate is to determine a monetary policy strategy, which allows the central bank to achieve its objectives (Bindseil, 2014). Monetary policy is geared towards influencing macroeconomic variables that are not under the direct control of the central bank. To pursue these objectives, the central bank needs to choose operational targets, which are targets that the central bank can directly control. Since the central bank's objectives tend to be in the real economy, the most direct operational targets have historically been the volume and sectoral distribution of private credit (Bezemer, Ryan-Collins, van Lerven, \& Zhang, 2018; Monnet, 2018). The pre2008 era saw broad convergence on short-term interest rates as the operational target of monetary policy, but since then central banks have broadened their interventions to influence long-term interest rates directly. Although exchange rate stability is often no longer a goal of monetary policy, it remains an important consideration for achieving domestic price stability (Moschella, 2015). Because monetary policy operations also have a crucial role in providing banks with short-term funding, the central bank must design its operational framework to look after these counterparties.

There is considerable variation in the extent to which central bank mandates address operational targets and instrument. Before the introduction of the Euro, the mandate of the German Bundesbank spelled out in meticulous detail what assets it was allowed to trade in. Today, the Federal Reserve is still only allowed to provide credit to individual and non-financial firms "in unusual and exigent circumstances" (Federal Reserve Act, article 13(3)). Other central banks, however, have a much more general power to trade in financial assets. The ECB, for example, is to pursue its objectives by "buying and selling outright (spot and forward) or under repurchase agreement and by lending or borrowing claims and marketable instruments, whether in euro or other currencies", as by trading in precious metals (ECB and ESCB status, Article 18). The mandate also permits the ECB to "conduct credit operations with credit institutions and other market participants, with lending being based on adequate collateral". But, crucially, what adequate means is not further specified. The ECB Governing Council can, by a two-third majority, decide on any "operational methods of monetary control as it sees fit" (ECB and ESCB status, Article 20). Periodic reviews of the monetary policy framework, such as those completed in 2020 by the Federal Reserve and in 2021 by the $\mathrm{ECB}$, typically take place without a say for elected governments $(\mathrm{ECB}, 2021$; FOMC, 2020).

The third step in the interpretation of the mandate is the actual setting of monetary policy (Bernanke, Laubach, Mishkin, \& Posen, 2001). This occurs in regular committee meetings. In setting monetary policy, the monetary policy committee chooses values for the operational targets with which to achieve its objectives. In setting monetary policy, central bankers tend to take its goals and the strategy as given and deliberate about the best way to act on it. This step is often emphasized in debates over central bank independence and it is here that the account of bureaucratic delegation fits best. Even at 
this stage, however, choices need to be made that go beyond establishing empirical facts and acting on them. Because the central bank has only incomplete knowledge of the state of the economy and the expected consequences of its policy interventions, the strategy rarely provides an unambiguous answer to what level the operational targets should have. Central bankers also have to decide on how to communicate their decisions (Braun, 2015).

The fourth step of interpretation is monetary policy implementation, which concerns the operations that central bankers use to steer the operational target (Bindseil 2006; 2014). Operations, in this context, are typically financial market transactions in which the central bank either trades in specific financial assets or engages in direct lending and borrowing transactions. The central bank sets rules for its open market operations and standing facilities, the reserve requirements imposed on counterparties and indeed the rules that govern which institutions are eligible as counterparties. In the day to day trading context, the market division decides which assets to buy and what to accept as collateral.

\section{Non-neutrality}

Even if it is admitted that central banks make choices, we might still wonder whether they are not ultimately of a technical nature, finding the means to achieve a well-defined end. It is in this sense that central bankers often describe their operations as neutral.

Drawing on the theorem of the long-run neutrality of money, central bankers claim that monetary policy does little more than guiding the economy to an optimal state (Friedman, 1968; Bernanke et al., 2001; Issing, 2008). However, it is uncontroversial that monetary policy can have a pervasive impact on the economy in the short term. The initial effects of lower rates and other forms of monetary stimulus are to reduce unemployment and boost economic output. According to the theorem of the long run neutrality of money, nonetheless, the economy has a long-term equilibrium determined by supply-side factors. Should the central bank try to push the economy to operate above its long-term equilibrium the benefits will be transient. Employment and output growth result in higher prices which undo the effects of the initial stimulus. Even worse, workers and firms come to expect inflation over time so that they anticipate and thereby undo the short-term stimulus. Maintaining the same level of stimulus requires ever more inflation. Thus, as Friedman famously concluded, "there is always a temporary trade-off between inflation and unemployment; there is no permanent trade-off." (Friedman, 1968, p. 11). The lesson that central bankers draw from the theorem of the long run neutrality of money is that monetary policy should only be used to push the economy towards its long-term equilibrium, but not beyond it. Establishing how far the economy is removed from the equilibrium is treated as a technical, not a political challenge.

As we have seen, however, neither the way in which the central banks define their targets nor the ways of pursuing them are determined by the mandate. Although it has always been clear that central bankers often cannot predict the impact of their policies (Blanchard \& Katz, 1997; Galbraith, 1997), recent work has turned to consider the political aspects of those choices. There is now more appreciation of the pervasive uncertainty that surrounds real-time monetary policy making (Abolafia, 2010; Best, 2016), the politics of economic forecasting (Mudge \& Vauchez, 2018), the measurement of decisive economic variables (Mügge, 2016; Heimberger \& Kapeller, 2017), and the 
trade-offs between financial and monetary stability (Tymoigne, 2009; Gabor \& Ban, 2016; Tucker, 2018, Chapter 20). Central bankers also dramatically disagree on the most basic questions concerning the causes of inflation (Tarullo, 2017; Rudd, 2021). In short, rather than steering the economy to its long-term equilibrium, central bankers make their own choices in how they pursue price stability.

The pursuit of price stability has its own distributive impact. Most attention in recent years has gone to quantitative easing (QE) operations, which are through to have disproportionately benefited wealthy households. To present just one startling statistic, the poorest $10 \%$ of UK households saw their wealth increase an estimated GBP 3,000, while the wealthiest $10 \%$ made average gains of GBP 350,000 as a result of QE operations by the Bank of England (Bunn, Pugh, and Yeates 2018). QE operations also have distributive effects by shaping private sector investment. Arguably, the wealth effect has received a disproportionate amount of attention. In fact, it is just one of many ways in which monetary policy affects economic distributions. Central banks seek to steer the business cycle by either boosting the economy or allowing it to go into recession. How the central bank does this and when it allows the economy to go into recession also has long-term effects on employment, wage growth and virtually every other economic indicator that affects the lives of people (Ball, 1993; Galbraith, 1997; Epstein \& Yeldan, 2009; Blanchard, Cerutti, \& Summers, 2015; Coibion, Gorodnichenko, Kueng, \& Silvia, 2017; Sokol \& Pataccini, 2021; Van Doorslaer \& Vermeiren, 2021).

There is also a second sense in which central bankers portray monetary policy as neutral, which concerns the impact of their operations on financial markets (van 't Klooster \& Fontan, 2020). In designing operations, central banks also pursue the dual objectives of protecting themselves against losses and market neutrality. Market neutrality of operations requires that beyond shaping markets to achieve the central bank's policy objectives, monetary policy should not benefit specific market participants, sectors, or asset classes. To this end, central bankers use various techniques of diversification and benchmarking or focus on government bonds and other public issuer assets.

In practice, however, the choice of instruments and the design of operations do have their own distributive consequences (Bindseil \& Papadia, 2009; CGFS, 2015; Peer, 2019). Central bank operations impact the availability of assets in financial markets directly, in the way that any market participant affects prices. Purchases of a certain asset class make it scarcer, while sales add to supply. Likewise, collateral eligibility also affects the demand for collateral of central bank counterparties. The mere announcement of a QE programme has immediate impact on market prices (Abidi \& Miquel-Flores, 2018). Because central banks seek to follow the market, their operations can also reproduce market failures. The European Central Bank's reliance on private credit ratings in evaluating sovereign bonds contributed to the European debt crisis (Orphanides, 2017). Recognizing that capital markets unduly benefit carbon intensive industries (Matikainen, Campiglio, \& Zenghelis, 2017), central banks are currently in the process of finding ways to move beyond market neutrality (BoE, 2021; ECB, 2021).

Rather than having narrow roles and simple objectives, their key role in the hybrid monetary constitution leads central bankers to juggle a wide range of responsibilities. Central bankers create financial markets, both as regulators and through their monetary policy operations. Their choices benefit the common good, but also specific socio- 
economic groups and financial market constituencies (Braun, 2018b; Prins, 2018). Hence, we should ask why the same standards of democratic accountability that apply to other areas of economic policy should not also apply to the monetary domain. This is the question that I now turn to.

\section{The ethics of central bank independence}

In the past decade, central bankers have, willingly or reluctantly, accepted new roles and proposed creative interpretations of their mandate to confront new challenges (Best, 2016; Dietsch, Claveau, \& Fontan, 2018; Goodhart \& Lastra, 2018; de Boer \& van 't Klooster, 2020). Although the legal text of the mandate in most cases remained essentially unchanged, central banks have experimented with a range of new instruments. Central banks also came to face new challenges far beyond that of maintaining price stability. Their financial stability objectives have expanded dramatically, moving from microprudential tasks targeted on individual institutions to macroprudential roles in stabilizing the financial system as a whole (Baker, 2013; Thiemann, 2019). Climate change, meanwhile, creates new challenges, which central bankers have added to their remit by focusing on the financial risk that it creates and the way in which financial institutions deal with these (Bolton, Depres, Pereira da Silva, Samama, \& Svartzman, 2020; Smoleńska \& van 't Klooster, 2021). Despite all these new roles, it remains largely to their discretion how, if at all, central banks contribute to their government's environmental and climate-related objectives.

What should we make of the immense discretion that central bankers currently hold from a normative perspective? I first ask whether there is a democratic objection against the very fact of assigning a high level of discretion to unelected officials, which I argue is not the case. Instead, answering the question what to make of the institutions of central bank independence requires much closer empirical and normative scrutiny.

\section{Is there are a democratic case against technocratic discretion?}

Bureaucratic delegation is widely recognised to be permissible in a democratic society (Richardson, 2002; Christiano, 2012). The only difficult normative question it raises is how exactly to demarcate the sort of choices that unelected officials are allowed to make from impermissible distributional choices. Accordingly, the account of central bank independence as bureaucratic delegation suggests a strict criterion for which roles in the public regulatory framework should be left to elected officials and which not. Unelected officials should not be setting their own goals and merely try to find ways to achieve goals assigned to them in the most efficient way (Tucker, 2018; cf. Skinner, 2021).

From this perspective, there is a simple answer to the question when major political choices can permissibly be delegated to unelected officials, namely: never. That answer, however, obscures the difficult normative issues raised by the prevalence of technocratic discretion in advanced capitalist societies today. Rather than denying that central bankers as a matter of fact make political choices, we should question the conditions under which they should be allowed to make them.

Even for constitutional theorists committed to a strong conception of popular sovereignty there are good arguments against a blanket prohibition of technocratic discretion (van 't Klooster, 2019, 2020). The first thing to note about democratic 
objections to central bank independence is their selectivity. Consider again the hybridity of existing monetary constitutions, wherein banks issue new money in the act of granting loans. Deciding who has access to finance, and under what conditions, can have life changing consequences and, hence, raises its own issues of justice (Meyer, 2018b, 2018a; Hockett \& James, 2020). Credit provision is subject to pervasive biases along class, gender and race fault lines (Ongena \& Popov, 2016; Baradaran, 2017; Quinn, 2019). Banks routinely ban individuals from opening a banking account for spurious moral reasons. Who gets financed also shapes the lives of individuals indirectly by determining broader economic developments shaping what industries blossom and which disappear. Today, as we already saw, carbon-intensive industries continue to benefit from generous access to capital markets. The same democratic worries brought to bear against technocrats might be put forward against bankers. So, what, if anything, makes power exercised by central bankers more problematic?

The permissibility of central bank independence only becomes an issue once there is a domain of public authority over money in the first place. In a largely private monetary constitution, there is very little for the public to decide hence the question of permissibility does not arise. But, surely that does not make such monetary system more democratic. Rather, we might very well wonder whether there are not pressing democratic reasons in favour of a pure public monetary constitution, which does away with private money creation altogether (Weber, 2018).

Of course, we should ask how much discretion unelected officials should have. This is particularly true when they are insulated from more traditional structures of democratic accountability. Nonetheless, recognizing the potential scope of political decisions that need to be made in any given monetary jurisdiction, minimizing discretion available unelected officials unduly constrains effective monetary governance. There are at least three kinds of reasons for giving final authority over important issues in the regulation of the hybrid monetary constitution to unelected officials (van 't Klooster, 2020, p. 591).

First, technocratic discretion is almost unavoidable. In theory, the legislature could seek to spell out the correct way of dealing with all important choices, but this would quickly defeat the purpose of delegation. Over time, new choices unavoidably emerge and require new responses. The capacity of the legislature to reflect on monetary policy is limited, since it only one amongst an endless list of topics of concern. It is unavoidable that governments, therefore, leave some difficult political choices to unelected officials. By enshrining the independence of the central bank in constitutional structures, the legislature decides that it will focus its attention elsewhere. Central bank independence implies that the legislature has more time to scrutinize the annual budget.

The argument for unavoidability quickly turns into an argument for the desirability of central bank independence (Blinder, 1999; Issing, 2008; Tucker, 2018). Governments might very well judge that it is better to leave some choices to unelected officials who have the time and expertise to decide how to deal with tricky political issues. A closely related problem is that of time-inconsistency (Kydland \& Prescott, 1977). Although governments may prefer low inflation in the long run, short term electoral pressures may undermine that commitment. A central bank with a clear price stability mandate allows the government to make its commitment to financial markets credible. In 
this sense, assigning an area of policymaking to the final authority of an independent agency can itself be seen as a part of economic policy.

The third consideration, which I think should be decisive from the perspective of popular sovereignty, is that whether or not to delegate monetary policy should itself be a topic of democratic decision-making. How much discretion technocrats should have with regard to their instruments and goals is itself a political question. The account of central bank independence as bureaucratic delegation invokes a neat distinction between permissible bureaucratic and impermissible technocratic discretion. The vagueness of that distinction, however, is not accidental and open to resolution through further conceptual clarification, but rather itself a legitimate topic of political disagreement. Moreover, evaluating the permissibility of central bank discretion should take into account a range of tricky normative and empirical issues, turning it into a subject of pervasive and potentially irresolvable disagreement. Making such choices is exactly what legislatures are meant to do in the first place.

\section{Central bank independence today}

Once we move beyond the simple story of bureaucratic delegation it becomes clear that the normative evaluation of the central bank's constitutional role unavoidably requires weighing a range of substantive and procedural considerations. In earlier work, I proposed a normative framework for answering that question focusing on the way that central bank independence shapes deliberation and decision-making on monetary policy (van 't Klooster, 2020). A justification for delegating monetary policy to an independent central bank should explain how it improves the quality of decision-making while involving acceptable losses of competences and policy instruments on the side of elected governments. Both sides of the equation, however, resist easy quantification. Most literature on the topic is authored by central bank researchers, who are extremely reluctant to challenge independence (Blinder, 1999; Dietsch et al., 2018, Chapter 4). Despite some recent work by political scientists, lawyers and other social scientists, we are currently still far removed from having a clear answer to important questions. Consider six open issues that deserve more detailed study.

The first thing to ask about independent central banks is to what extent their choices really diverge from the policy preferences of citizens and their elected representatives. Traditionally, central bankers are thought to make better decisions because they are shielded from electoral pressures. In practice, however, popular opinion does matter to central banks. In fact, they tend to be acutely aware of their own tenuous legitimacy and this shapes their decision-making (Braun, 2018a; Ronkainen \& Sorsa, 2018; van 't Klooster \& Fontan, 2020). The rescue of banks in 2008 involved discretionary interventions on the side of central banks, but generally in coordination with the treasury and other government agencies (Calomiris \& Khan, 2015; Bateman, 2020). The 2020 COVID-19 pandemic saw central bankers move beyond earlier taboos in lending on an unprecedented scale to governments and crisis-struck firms, but again they did so following a broad societal consensus.

If independent central banks indeed tend to follow the policy preferences of their domestic government, this would clearly alleviate the tension between popular sovereignty and central bank independence. A particularly clear illustration of how central banks follow national positions is visible in recent central bank concern for 
environmental issues. Climate change was virtually ignored before the 2015 Paris Agreement, whose Article 2.1c requires "making finance flows consistent with a pathway towards low greenhouse gas emissions and climate resilient development". From 2015 onwards, the Bank of England, the Banque de France and other, mostly European central banks became more vocal proponents of green priorities and founded the Network for Greening the Financial System (NGFS). Under the Donald Trump presidency, the US Federal Reserve did not join the NGFS and rarely addressed the issue of climate change in its public statements. The Fed announced it would become a member of the NGFS a few days after Joe Biden was elected.

Irrespective of how this first debate turns out, we should still worry about the informal nature of the existing arrangements of accountability. A long-standing worry with regard to central bank independence is that it disperses responsibility such that neither elected governments nor central banks are accountable for decisions (Friedman, 1962). The creation of an independent central bank thus transforms the role of the executive, which gives up control over monetary policy. Parliaments no longer oversee monetary policy decisions as part of the legislatures role in the parliamentary control of executive taxation, borrowing and spending. The central bank board, whose member deliberate behind closed doors, sets monetary policy within the constraints imposed on it by the monetary constitution. As a consequence, central bankers can always blame governments and markets when things go awry. This problem is not new, but rather a perennial risk associated with central bank independence. As Milton Friedman already observed

In the past few years, I have read through the annual reports of the Federal Reserve System from 1913 to date, seriatim. One of the few amusing dividends from that ordeal was seeing the cyclical pattern that shows up in the potency that the authorities attribute to monetary policy. In years when things are going well, the reports emphasize that monetary policy is an exceedingly potent weapon and that the favorable course of events is largely a result of the skilful handling of this delicate instrument by the monetary authority. In years of depression, on the other hand, the reports emphasize that monetary policy is but one of many tools of economic policy, that its power is highly limited, and that it was only the skillful handling of such limited powers as were available that averted disaster. (1962, p. 233)

A similar dynamic of responsibility dispersal can be observed recently with regard to the distributive effects of monetary policy. Central bankers argue that they were forced to implement QE by the absence of fiscal policy. Within the mandate assigned to them by governments, QE was the only tool available to avert a recession (Haldane, 2014). Although central banks moved beyond their existing toolkit to address the post-crisis recession, they sought to present their new policies as largely continuous with pre-crisis practices. Meanwhile, politicians routinely blame central banks for the adverse effects of accommodative monetary policy (or, more recently, inflation caused by political mismanagement of supply chains). The overall result is that no one accepts responsibility for general trajectory of the economy. Public scrutiny is also limited: Citizens have zoned out from monetary and financial politics, which they in any case have a very little ability to influence. 
A third question concerns what the absence of public contestation does with the broader democratic system. By ceding the power over money, politicians lose a tool to improve the lives of their constituents. Political scientists worry that the broader process of depoliticization, in particular with regard to economic policy, hollows out democratic politics, which in turn drives political disengagement and benefits the far right (Hay, 2007; Mair, 2013; Fawcett, Flinders, Hay, \& Wood, 2017). Money remains an arcane topic, however, whose impact on the lives of individuals is not a natural topic for public scrutiny even in the absence of independent central banks. This question is particularly tricky to study not just because of the complex social mechanisms involved but because the absence of political systems with governmental control of monetary policy precludes comparative studies.

Since political insulation is supposed to improve the quality of central bank decision-making a third topic to consider is its potential benefits. Although central bankers are meant to be shielded from electorates by their independence, they can never afford to lose public support altogether. The Bundesbank carefully built its independent source of public support, which allowed it to use popular opinion to achieve its goals (Mee, 2019). Few central banks have been able to replicate that feat (Lokdam, 2020). In presenting their role as continuous with that of other government agencies, central bankers seek to foster a public perception of monetary policy as pursuing clearly defined and broadly beneficial goal by means of a limited set of instruments. Even if that account is as we saw false, the efforts of central bankers to conform to it do shape their policies (van 't Klooster \& Fontan, 2020). Consider the choice to implement QE when the conventional tool of steering short-term interest rates became ineffective. QE was one of many tools available to central banks to supplement their pre-crisis practices. To what extent was the choice for QE and the way in which it was implemented motivated by the desire to maintain continuity with pre-crisis practices? The choice for QE, as we saw, did have its own distributive effects, which might have been different. The central bank's efforts to sustain legitimacy thus comes with its own social costs. Would it then simply be better to accept that central bankers make political choices and hope that they do the best they can? Or does the central bank's quest for legitimacy have its own beneficial consequences too? (Skinner, 2021)

Democratic insulation not only shapes the central bank's policy space, but also gives a very specific shape to deliberation internal to the central bank. Central banking, in contrast to government-led policy, is meant to be a dispassionate affair subordinate to the common good. The importance of technical expertise, however, also means that central bankers often hail from a narrow range of career background in the financial sector or government. In a comparative study of twenty central banks between 1950 and 2000, Adolph $(2013$, p. 70$)$ shows that $95 \%$ of central bankers are men and $47 \%$ had spent their entire career in finance or government. Since low inflation is a crucial priority for the financial sector, whose assets tend to have a fixed nominal value, it is striking that those central bankers with a finance background prefer higher rates (and are hence willing to accept lower employment and growth). This suggests that central banks would take a broader range of interests into account if their board member were drawn from a broader range of societal backgrounds. A second way in which the existing institutions of central bank independence shape deliberation results from the expertise available within central banks and the technical vocabulary in which choices are debated (Marcussen, 2009; Abolafia, 2010, 2012). The central bank's primary expertise concerns financial markets and business cycles, but many questions concerning the most desirable future path of 
economic development go beyond these topics. Consider once more whether central banks should take a more active role in stopping climate change. The climate transition will unavoidably result in certain industries flourishing and others disappearing. Employees will lose their jobs and consumers will have to adapt their lifestyles. Scholars of central banking should do more to explore how the specific expertise and career backgrounds of central bankers affects their ability to make these decisions.

To conclude: What should be done if we decide that central banks have in fact become too independent? Note that there is no strict contraction between formal independence and some degree of coordination with governments (de Boer \& van 't Klooster, 2020, 2021; Baer, Campiglio, \& Deyris, 2021; Monnet, 2021). The mandate of the Bank of England explicitly invites the Treasury to weigh in on key strategic choices. More generally, where mandates contain a blanket provision in favour of supporting economic policy, governments could do more to weigh on the priorities that the central bank should support. One modality of coordination is to incorporate existing legislation into the design of monetary policy operations. For example, public taxonomies for green investment can be the basis for deciding which sectors of the economy monetary policy should support (van 't Klooster \& van Tilburg, 2020). In this way, coordination could improve the quality of decision-making. It could also improve the legitimacy of political choices made in the face of new challenges. A major question going forward will accordingly be how to structure effective coordination and whether, if at all, that would unduly limit the central bank's independence.

\section{Conclusion}

Legal and political theorists face many open questions when it comes to the institutional structures of central bank independence. Holding the most powerful levers of economic policy, they could achieve a wide range of objectives beyond price stability. Central banks could do a lot more to move the economy away from catastrophic environmental collapse, but should they? More generally, should central banks take the distributive effects of their policy into account when pursuing low inflation? Accounts of central bank independence as a case of bureaucratic delegation greatly simplify the moral questions raised by central banks. The most basic question to ask does not concern central banks per se, but rather the very shape of the monetary constitution. The democratic legitimacy of central banks can only become an issue after deciding where the private domain of money creation starts. The question of when delegation is permissible cannot be neatly separated from the question of how to govern the economy, so that the design of a central bank raises a wide range of procedural and substantive issues. This chapter has sought to bring the terrain that remains to be explored into focus. The past decades saw central bankers acquire an increasingly prominent role in economic policy. This makes a re-evaluation of the central bank's unique constitutional status highly pertinent. If it turns out that central bankers are not particularly well placed to deal with the major economic policy challenges of the $21^{\text {st }}$ century, existing constitutional structures are no longer fit for purpose and need to be revised.

\section{Recommended Bibliography (10-15 titles)}

Adolph, C. (2013). Bankers, Bureaucrats, and Central Bank Politics: The Myth of Neutrality. New York: Cambridge University Press. 
Bateman, W. (2020). Public Finance and Parliamentary Constitutionalism: Cambridge: Cambridge University Press.

Baradaran, M. (2017). The Color of Money: Black Banks and the Racial Wealth Gap. Harvard University Press.

Bernanke, B., Laubach, T., Mishkin, F., \& Posen, A. (2001). Inflation targeting: Lessons from the international experience. Princeton, NJ: Princeton Univ. Press.

Braun, B., \& Downey, L. (2020). Against Amnesia: Re-Imagining Central Banking (Discussion Note No. 2020/01). Council on Economic Policies.

Coibion, O., Gorodnichenko, Y., Kueng, L., \& Silvia, J. (2017). Innocent Bystanders? Monetary policy and inequality. Journal of Monetary Economics, 88, 70-89.

Conti-Brown, P. (2016). The Power and Independence of the Federal Reserve. Princeton University Press.

Desan, C. (2014). Making Money: Coin, Currency, and the Coming of Capitalism. Oxford University Press.

Dietsch, P., Claveau, F., \& Fontan, C. (2018). Do Central Banks Serve the People? Cambridge: Polity.

Friedman, M. (1962). Should there be an independent monetary authority? In L. Yeager (Ed.), In Search of a Monetary Constitution (Reprint 2014, pp. 219-243). Berlin, Boston: De Gruyter.

Hockett, R., \& Omarova, S. (2017). The Finance Franchise. Cornell Law Review, 102, 1143.

Mehrling, P. (2010). The New Lombard Street: How the Fed Became the Dealer of Last Resort. Princeton University Press.

Monnet, E. (2021). La Banque Providence: Démocratiser les banques centrales et la monnaie. Paris: Seuil.

Pistor, K. (2013). A Legal Theory of Finance. Journal of Comparative Economics, 41, $315-330$.

Tucker, P. (2018). Unelected Power: The Quest for Legitimacy in Central Banking and the Regulatory State. Cambridge (MA): Harvard University Press.

\section{Bibliography}

Abidi, N., \& Miquel-Flores, I. (2018). Who Benefits from the Corporate QE? A Regression Discontinuity Design Approach (ECB Working Paper No. 2145). Frankfurt: European Central Bank.

Abolafia, M. Y. (2010). Narrative Construction as Sensemaking: How a Central Bank Thinks. Organization Studies, 31, 349-367.

Abolafia, M. Y. (2012). Central Banking and the Triumph of Technical Rationality. In K. Knorr-Cetina \& A. Preda (Eds.), The Oxford Handbook of the Sociology of Finance (pp. 94-112). Oxford: Oxford University Press.

Admati, A., \& Hellwig, M. (2014). The Bankers' New Clothes: What's Wrong with Banking and What to Do about It. Princeton University Press.

Adolph, C. (2013). Bankers, Bureaucrats, and Central Bank Politics: The Myth of Neutrality. New York: Cambridge University Press.

Arnon, A. (2010). Monetary Theory and Policy from Hume and Smith to Wicksell: Money, Credit, and the Economy. Cambridge University Press.

Baer, M., Campiglio, E., \& Deyris, J. (2021). It takes two to dance: Institutional dynamics and climate-related financial policies. Ecological Economics, 190, 107210. 
Baker, A. (2013). The New Political Economy of the Macroprudential Ideational Shift. New Political Economy, 18, 112-139.

Ball, L. (1993). What Determines the Sacrifice Ratio? (Working Paper No. 4306). National Bureau of Economic Research.

Baradaran, M. (2017). The Color of Money: Black Banks and the Racial Wealth Gap. Harvard University Press.

Barontini, C., \& Holden, H. (2019). Proceeding with Caution: A Survey on Central Bank Digital Currency. Basel: Bank for International Settlements.

Bateman, W. (2020). Public Finance and Parliamentary Constitutionalism. Cambridge: Cambridge University Press.

Bernanke, B., Laubach, T., Mishkin, F., \& Posen, A. (2001). Inflation targeting: Lessons from the international experience. Princeton, NJ: Princeton Univ. Press.

Best, J. (2016). Rethinking Central Bank Accountability in Uncertain Times. Ethics \& International Affairs, 30, 215-232.

Bezemer, D., Ryan-Collins, J., van Lerven, F., \& Zhang, L. (2018). Credit where it's due: $A$ historical, theoretical and empirical review of credit guidance policies in the 20th century (UCL Institute for Innovation and Public Purpose Working Paper Series No. 2018-11). Retrieved from https://www.ucl.ac.uk/bartlett/publicpurpose/publications/2018/nov/credit-where-its-due

Bindseil, U. (2014). Monetary policy operations and the financial system. New York: Oxford University Press.

Bindseil, U., \& Papadia, F. (2009). Risk management and market impact of central bank credit operations. In U. Bindseil, F. Gonzalez, \& E. Tabakis (Eds.), Risk Management for Central Banks and Other Public Investors (pp. 271-302). Cambridge University Press.

BIS. (2014). Re-thinking the lender of last resort. Basel: Bank for International Settlements.

Blanchard, O., Cerutti, E., \& Summers, L. (2015). Inflation and Activity - Two Explorations and their Monetary Policy Implications (Working Paper No. 21726). National Bureau of Economic Research.

Blanchard, O., \& Katz, L. F. (1997). What We Know and Do Not Know About the Natural Rate of Unemployment. The Journal of Economic Perspectives, 11, 51-72.

Blinder, A. (1999). Central banking in theory and practice. Cambridge, Mass.: MIT Press.

BoE. (2021). Options for greening the Bank of England's Corporate Bond Purchase Scheme [Discussion Paper]. London: Bank of England.

Bolton, P., Depres, M., Pereira da Silva, L. A., Samama, F., \& Svartzman, R. (2020). The green swan: Central banking and financial stability in the age of climate change. Basel: Bank for International Settlements.

Braudel, F. (1982). Civilization and Capitalism, 15th-18th Century, Vol. II: The Wheels of Commerce. University of California Press.

Braun, B. (2015). Governing the future: The European Central Bank's expectation management during the Great Moderation. Economy and Society, 44, 367-391.

Braun, B. (2018a). Central bank planning? Unconventional monetary policy and the price of bending the yield curve. In J. Beckert \& R. Bronk (Eds.), Uncertain Futures: Imaginaries, Narratives, and Calculation in the Economy (pp. 194-218). Oxford: Oxford University Press.

Braun, B. (2018b). Central banking and the infrastructural power of finance: The case of ECB support for repo and securitization markets. Socio-Economic Review. https://doi.org/10.1093/ser/mwy008 
Braun, B., \& Downey, L. (2020). Against Amnesia: Re-Imagining Central Banking (Discussion Note No. 2020/01). Council on Economic Policies.

Brennan, H., \& Buchanan, J. M. (1980). The power to tax: Analytical foundations of a fiscal constitution. Cambridge: Cambridge University Press.

Brummer, C. (2015). Soft Law and the Global Financial System. Cambridge: Cambridge University Press.

Calomiris, C. W., \& Khan, U. (2015). An Assessment of TARP Assistance to Financial Institutions. Journal of Economic Perspectives, 29, 53-80.

CGFS. (2015). Central bank operating frameworks and collateral markets (Committee on Payments and Market Infrastructures Papers No. 53). Basel: Bank for International Settlements.

Christiano, T. (2012). Rational deliberation among experts and citizens. In J. Mansbridge \& J. Parkinson (Eds.), Deliberative Systems: Deliberative Democracy at the Large Scale (pp. 27-51). Cambridge: Cambridge University Press.

Coibion, O., Gorodnichenko, Y., Kueng, L., \& Silvia, J. (2017). Innocent Bystanders? Monetary policy and inequality. Journal of Monetary Economics, 88, 70-89.

Constitute Project. (2020). Constitute The World's Constitutions to read, search, and compare. Retrieved 9 September 2020, from Constituteproject.org website: https://www.constituteproject.org/

de Boer, N., \& van 't Klooster, J. (2020). The ECB, the courts and the issue of democratic legitimacy after Weiss. Common Market Law Review, 57, 1689-1724.

de Boer, N., \& van 't Klooster, J. (2021). The ECB's neglected secondary mandate: An inter-institutional solution. Brussels: Positive Money Europe.

Desan, C. (2014). Making Money: Coin, Currency, and the Coming of Capitalism. Oxford University Press.

Dietsch, P., Claveau, F., \& Fontan, C. (2018). Do Central Banks Serve the People? Cambridge: Polity.

Dikau, S., \& Volz, U. (2021). Central bank mandates, sustainability objectives and the promotion of green finance. Ecological Economics, 184, 107022.

ECB. (2021, July 8). The ECB's monetary policy strategy statement [2021]. Retrieved 18 July 2021, from European Central Bank website: https://www.ecb.europa.eu/home/search/review/html/ecb.strategyreview_monpo 1_strategy_statement.en.html

Epstein, G. A., \& Yeldan, A. E. (2009). Beyond Inflation Targeting: Assessing the Impacts and Policy Alternatives. Edward Elgar Publishing.

Fawcett, P., Flinders, M., Hay, C., \& Wood, M. (2017). Anti-Politics, Depoliticization, and Governance. In Anti-Politics, Depoliticization, and Governance (pp. 3-25). Oxford University Press.

FOMC. (2020). Statement on Longer-Run Goals and Monetary Policy Strategy. Washington, DC: Federal Open Market Committee.

Friedman, M. (1962). Should there be an independent monetary authority? In L. Yeager (Ed.), In Search of a Monetary Constitution (Reprint 2014, pp. 219-243). Berlin, Boston: De Gruyter.

Friedman, M. (1968). The Role of Monetary Policy. American Economic Review, 58, 117.

Gabor, D., \& Ban, C. (2016). Banking on bonds: The new links between states and markets. JCMS: Journal of Common Market Studies, 54, 617-635.

Gabor, D., \& Vestergaard, J. (2016). Towards a Theory of Shadow Money [INET Working Paper]. Institute for New Economic Thinking. 
Galbraith, J. K. (1997). Time to Ditch the NAIRU. The Journal of Economic Perspectives, 11, 93-108.

Goodhart, C., \& Lastra, R. (2018). Populism and Central Bank Independence. Open Economies Review, 29, 49-68.

Graziani, A. (2003). The Monetary Theory of Production. Cambridge: Cambridge University Press.

Haldane, A. (2014, May). Unfair Shares. Presented at the Bristol Festival of Ideas event, Bristol.

Hay, C. (2007). Why We Hate Politics. Cambridge: Polity Press.

Heimberger, P., \& Kapeller, J. (2017). The performativity of potential output: Procyclicality and path dependency in coordinating European fiscal policies. Review of International Political Economy, 24, 904-928.

Hockett, R., \& James, A. (2020). Money from Nothing: Or, why se should stop worrying about debt and learn to love the Federal Reserve. New York: Melville House.

Hockett, R., \& Omarova, S. (2017). The Finance Franchise. Cornell Law Review, 102, 1143.

Ingham, G. K. (2004). The Nature of Money. Cambridge and Malden, MA: Polity.

Issing, O. (2008). The Birth of the Euro. Cambridge; New York: Cambridge University Press.

Jackson, A., \& Dyson, B. (2012). Modernising Money: Why Our Monetary System is Broken and How it Can be Fixed. London: Positive Money.

Johnson, J., Arel-Bundock, V., \& Portniaguine, V. (2019). Adding rooms onto a house we love: Central banking after the global financial crisis. Public Administration, 97, 546-560.

Kumhof, M., \& Benes, J. (2012). The Chicago Plan Revisited [IMF Working Paper 12/202]. Washington, D.C.: International Monetary Fund.

Kydland, F., \& Prescott, E. (1977). Rules Rather than Discretion: The Inconsistency of Optimal Plans. Journal of Political Economy, 85, 473-491.

Lastra, R. (2015). International Financial and Monetary Law (2nd ed.). Oxford: Oxford University Press.

Lokdam, H. (2020). 'We Serve the People of Europe': Reimagining the ECB's Political Master in the Wake of its Emergency Politics. JCMS: Journal of Common Market Studies, 58, 978-998.

Mair, P. (2013). Ruling the Void. London: Verso.

Marcussen, M. (2009). Scientization of Central Banking: The Politics of A-Politicization. In K. H. F. Dyson \& M. Marcussen (Eds.), Central banks in the age of the euro: Europeanization, convergence, and power (pp. 373-390). Oxford: Oxford University Press.

Matikainen, S., Campiglio, E., \& Zenghelis, D. (2017). The climate impact of quantitative easing. London: Grantham Research Institute on Climate Change and the Environment.

Mee, S. (2019). Central Bank Independence and the Legacy of the German Past. Cambridge: Cambridge University Press.

Mehrling, P. (2010). The New Lombard Street: How the Fed Became the Dealer of Last Resort. Princeton University Press.

Meyer, M. (2018a). The Ethics of Consumer Credit: Balancing Wrongful Inclusion and Wrongful Exclusion. Midwest Studies In Philosophy, 42, 294-313.

Meyer, M. (2018b). The Right to Credit. Journal of Political Philosophy, 26, 304-326.

Monnet, E. (2018). Controlling Credit: Central Banking and the Planned Economy in Postwar France, 1948-1973. Cambridge University Press. 
Monnet, E. (2021). La Banque Providence: Démocratiser les banques centrales et la monnaie. Paris: Seuil.

Moore, B. J. (1988). Horizontalists and verticalists: The macroeconomics of credit money. Cambridge and New York: Cambridge University Press.

Moschella, M. (2015). Currency wars in the advanced world: Resisting appreciation at a time of change in central banking monetary consensus. Review of International Political Economy, 22, 134-161.

Mudge, S. L., \& Vauchez, A. (2018). Too Embedded to Fail: The ECB and the Necessity of Calculating Europe. Historical Social Research / Historische Sozialforschung, $43,248-273$.

Mügge, D. (2016). Studying macroeconomic indicators as powerful ideas. Journal of European Public Policy, 23, 410-427.

Murau, S. (2017). Shadow money and the public money supply: The impact of the 20072009 financial crisis on the monetary system. Review of International Political Economy, 24, 802-838.

Nakamoto, S. (2008). Bitcoin: A peer-to-peer electronic cash system. Decentralized Business Review, 21260.

Ongena, S., \& Popov, A. (2016). Gender Bias and Credit Access. Journal of Money, Credit and Banking, 48, 1691-1724.

Orphanides, A. (2017). ECB Monetary Policy and Euro Area Governance: Collateral Eligibility Criteria for Sovereign Debt (Working Paper No. 5258-17). Cambridge (MA): MIT Sloan School.

Peer, N. O. (2019). Negotiating the Lender of Last Resort: The 1913 Federal Reserve Act as a Debate Over Credit Distribution. New York University Journal of Law \& Business, 15, 367-452.

Pistor, K. (2013). A legal theory of finance. Journal of Comparative Economics, 41, 315330.

Prins, N. (2018). Collusion: How Central Bankers Rigged the World. New York: Nation Books.

Quinn, S. L. (2019). American bonds: How credit markets shaped a nation. Princeton, NJ: Princeton University Press.

Richardson, H. S. (2002). Democratic Autonomy: Public Reasoning about the Ends of Policy. Oxford: Oxford University Press.

Ricks, M. (2016). The Money Problem: Rethinking Financial Regulation. Chicago: University of Chicago Press.

Ronkainen, A., \& Sorsa, V.-P. (2018). Quantitative Easing Forever? Financialisation and the Institutional Legitimacy of the Federal Reserve's Unconventional Monetary Policy. New Political Economy, 23, 711-727.

Rudd, J. B. (2021). Why Do We Think That Inflation Expectations Matter for Inflation? (And Should We?). In Finance and Economics Discussion Series (No. 2021-062). Board of Governors of the Federal Reserve System (U.S.).

Ryan-Collins, J. (2017). Breaking the taboo: A history of monetary financing in Canada, 1930-1975: Monetary financing. The British Journal of Sociology, 68, 643-669.

Selgin, G. A. (1988). The theory of free banking: Money supply under competitive note issue. Rowman \& Littlefield pub Inc.

Skinner, C. (2021). Central Bank Activism. Duke Law Journal, 71, 247-328.

Smoleńska, A., \& van 't Klooster, J. (2021). A risky bet: Should the EU choose a microprudential or a credit guidance approach to climate risk? (104 No. ID 3949541). Frankfurt. https://doi.org/10.2139/ssrn.3949541 
Sokol, M., \& Pataccini, L. (2021). Financialisation, regional economic development and the coronavirus crisis: A time for spatial monetary policy? Cambridge Journal of Regions, Economy and Society, rsab033.

Tarullo, D. K. (2017). Monetary policy without a working theory of inflation (Hutchins Center Working Paper No. 33). Washington: Brookings Institution.

Thiemann, M. (2019). Is resilience enough? The macroprudential reform agenda and the lack of smoothing of the cycle. Public Administration, 97, 561-575.

Tucker, P. (2018). Unelected Power: The Quest for Legitimacy in Central Banking and the Regulatory State. Cambridge (MA): Harvard University Press.

Turner, A. (2015). The Case for Monetary Finance - An Essentially Political Issue. Washington, D.C.: International Monetary Fund.

Tymoigne, E. (2009). Central banking, asset prices and financial fragility. London: Routledge.

Van Doorslaer, H., \& Vermeiren, M. (2021). Pushing on a String: Monetary Policy, Growth Models and the Persistence of Low Inflation in Advanced Capitalism. New Political Economy, 26, 797-816.

van 't Klooster, J. (2018). How to make money: Distributive justice, finance, and monetary constitutions ( $\mathrm{PhD}$ thesis). University of Cambridge, Cambridge.

van 't Klooster, J. (2019). Central banking in Rawls's Property-Owning Democracy. Political Theory, 47, 674-698.

van 't Klooster, J. (2020). The Ethics of Delegating Monetary Policy. Journal of Politics, $82,587-599$.

van 't Klooster, J., \& Fontan, C. (2020). The Myth of Market Neutrality: A Comparative Study of the European Central Bank's and the Swiss National Bank's Corporate Security Purchases. New Political Economy, 25, 865-879.

van 't Klooster, J., \& van Tilburg, R. (2020). Targeting a sustainable recovery with Green TLTROs. Positive Money Europe \& Sustainable Finance Lab.

Weber, B. (2018). Democratizing Money? Cambridge: Cambridge University Press.

Yeager, L. (1962). In Search of a Monetary Constitution (Reprint 2014). Berlin, Boston: De Gruyter. 